\title{
AN ANALYSIS OF CENTRAL AMERICA AND EASTERN EUROPE REVEALED COMPARATIVE ADVANTAGES
}

\author{
Mauricio Garita \\ Universidad Rafael Landivar, Guatemala \\ Jose Godinez \\ Merrimack College, North Andover, MA
}

\begin{abstract}
The present study applies the revealed comparative advantages through the Balassa Index to determine the comparative advantages, disadvantages, and intra-product commerce tendencies between Central America and Eastern Europe with the purpose of determining the possibility of a free trade agreement for Central America. The approach of the study is through the connection between the European Economic Union and the Central American Common market, which shares a common background and relates them to research of Bela Balassa (1965) to determine how commerce between Central America and Eastern Europe has performed and the possibilities of growth that this commerce has through a free trade agreement. The study demonstrates the importance of analyzing competitive advantages. This paper presents the difference in competitive advantage between Eastern Europe and Central American establishing the benefits when negotiating a free trade agreement between both economic blocks. Therefore, analyzing and negotiating between products of competitive advantages may lead to a more sustainable economic growth.
\end{abstract}

Keywords: Balassa Index, free trade, Central America, Eastern Europe, European Union, Central American Common Market

\section{INTRODUCTION}

The Central American region has a long history of international trade dating back to the $19^{\text {th }}$ century (Behrman, 1974). Initially the region received foreign direct investment (FDI), mainly from the United States, which was primarily export-oriented and/or natural resource seeking. However, after WWII the region shifted toward manufacturing for local consumption (Biglaiser \& De Rouen, 2006). Despite the attractiveness of the region, local governments had a detrimental influence on foreign businesses by exercising significant regulative powers and enforcing them randomly (Grosse, 1989). It was not until the 1980s that local governments began opening the region to foreign firms, fuelled by the need of local governments of foreign exchange (Trevino, et al., 2004).

Due to the prohibition of most imports and restriction of FDI to the region, many countries created an unattractive business climate to foreign firms. Exacerbating this problem, indigenous firms were not able to acquire the required resources and capabilities to compete outside the region. These policies led to closed economies that did not open to foreign commerce until the 1980s (Trevino, et al., 2004). Nevertheless, during the past three decades, the Central American countries have employed market-oriented reforms in order to make the countries more attractive to foreign investment and to make their companies more competitive overseas (Rodrik, 1996). These reforms included changes in tax laws, liberalization of trade, privatisation, financial reform, and the removal of barriers to international capital flows (Biglaiser \& De Rouen, 2006).

While the Central American countries have signed several free trade agreements (FTAs) with different countries, the region as a whole might have more chances of economic growth with future FTAs if the agreements are signed as a 
region (Kose \& Rebucci, 2005). Nevertheless, such agreements have to be carefully evaluated in order to determine the possible benefits as well as possible drawbacks derived from them. For this reason, this study analyzed the comparative advantages of an FTA between Central America and the European Economic Union with the aid of the Balassa Model. This paper also expands our understanding of the comparative advantage theory by comparing two regions perceived as developing and by analyzing the agreement before it happens, instead of just studying past effects.

To analyze the comparative advantage of a FTA between Central America and Central Europe this paper firstly presents an overview of the existing literature. Secondly, the Balassa Model is utilized to analyze the data. Finally, a discussion, conclusion, and recommendations are provided.

\section{LITERATURE REVIEW ON COMPARATIVE ADVANTAGE AND TRADE}

David Ricardo proposed the model of commercial exchange in 1817 to understand the reasons of international commerce and the growth of the economies in a mercantilist society (Ricardo, 1951; Polanco, 2012). In the model, Ricardo explained that countries, when initializing commerce, had advantages that differentiated and motivated them to engage in commerce. This neoclassical theory explained that if advantages are taken into account, free commercial exchange between countries could only be constructive (Anchorena, 2009). David Ricardo's theory added to the explanation of Adam Smith concerning advantages, since Smith thought that countries should only participate in commerce if they had absolute advantages (Sutherland, 2008). Absolute advantages can be defined as the ability of a country to produce more of a good or service than the other country he is trading with by using the same amount of resources (Lee, Rhee, \& Lee, 2013). Smith proposed that if there was no government involved in trade and, if individuals could act in their best interest, then the welfare would increase.

According to David Ricardo, the optimal economic level, concerning commerce, is when countries export the goods and services on which they have a comparative advantage and import those goods and services on which they do not (Arias-Segura \& Segura-Ruiz, 2004). Comparative advantage principle relied on the concept of specialization, considering that if a country is relatively better at producing a product or service this product or service should be favored for exportation. This relativeness will lead the country into specialization and therefore the country will be in a comparative advantage when engaging in trade (Samuelson, 1969). As a result, specialization will lead to a more precise competitiveness and a more prolific market.

The discussion took place between the "neoclassical theory" that centers in Smith's contribution and the "neoclassicist" that supports David Ricardo's theory of comparative advantage, which centers that such advantages promote a better setting for competition and economic growth (Hunt \& Morgan, 1995). The search for a better setting for competition and economic growth leads to the analysis of competitive advantages centered on the principle that resources are limited but necessities are limitless. Therefore, the comparison between countries based on comparisons of economic costs, elasticity, production, capacity of exportation and the relation between exports and imports have guided free trade policies during the last century. The Balassa index bases the comparison of exports to the country or economic group and compares it to the exportations of the World with the purpose of determine if the effort of creating commerce to a certain country or economic group is worth the hassle. The Balassa index, also known as revealed comparative advantages or RCA, measures the comparative advantage at a point in time and between years to compare if important changes are being made concerning competitiveness (Cai, Leung, \& Hishamunda, 2009).

Over the years, scholars have utilized the principles of comparative advantage to analyze the catching-up process of industrialization in latecomer economies, which is composed of: (a) a basic pattern (i.e., a single industry grows tracing out the three successive curves of production, import, and export) and (b) a divergent pattern in which industries are diversified and upgraded from consumer goods to capital goods and/or from simple to more sophisticated products (Kojima, 2000). Based on these patterns, Kojima (2000) predicted that the accumulation of human resources and capital causes economies to diversify to more capitalintensive industries and then to move to more efficient production methods. Those 
diversification/rationalization patterns are repeated in moving an economy towards the higher stages of production and export. Based on the comparative advantage analysis, many scholars have argued that the emphasis on trade and foreign direct investment (FDI) has given certain geographical areas of the world the key for economic growth. This assertion is welldocumented; firstly, for the European (Benedictis \& Tajoli, 2007) and secondly, for the Asian exceptional transformation in the past decades (Kojima, 1985; Hobday, 1995).

Despite the popularity of the methods used to analyze the comparative advantage between regions, there are very few rigorous theoretical and empirical works analyzing the comparative advantages of regions outside the triad. Also, when analyzing the comparative advantage between regions the flows of trade have been analyzed from a developed region to a developing one. For this reason, it is important for the existing literature to analyze the comparative advantage of two developing regions in order to see if the theory is still valid, which is the motivation for this paper. Moreover, in this paper the comparative advantage theory is used in a novel manner, which is to predict possible outcomes rather than to analyze past events.

\section{THE ECONOMIC UNION OF EUROPE AND CENTRAL AMERICA}

Europe and Central America searched, at the same time, for an economic unity. In 1951, Central America created the Organization of Central American States (ODECA) as a forum for motivating communication between its members concerning economic aspects and cooperation. In 1958, Central America signed the Multilateral Treaty on Free Trade and Central American Integration, which established an area of free commerce for the next ten years (Kose \& Rebucci, 2005).

In 1960, Guatemala, Honduras, Nicaragua and El Salvador signed the General Treaty of Central American Economic Integration, which created an economic framework that lead to establish the Central American Common Market to which Costa Rica adhered two years later. The purpose of the Common Market was to promote the comparative advantages of the countries so that, as a result, Central America had an accelerated economic growth. The inception of this treaties is attributed United Nations Economic Commission for Latin America (ECLAC) and was motivated by the necessity of creating small economies capable to substitute their imports (Soto-Acosta, 1986).

In 1957, Europe began its economic integration when the European Council was founded based on the Treaty of Rome. The process started by creating preferential trading areas followed by the free trade areas, customs unions, single market, economic and monetary union; this led to the complete economic integration (European Commission, 2013). The original members of the European Union were Belgium, France, Germany, Italy Luxemburg and the Netherlands. In 2004, Poland and Czech Republic, considered as part of Eastern Europe, were included in the European Union as part of the Fifth Enlargement (Summa, 2008). The purpose of the European Economic Community was in principle the same as the Central American Common Market because it sought to establish a single market in which goods, capital services, and people could move freely; therefore, enhancing the comparative advantages (Dinan, 2005).

On 2012, the Latin America meeting with Central and Eastern Europe in Vienna opened a stronger discussion concerning the benefits of trade between the two economic regions. From Central America, only Guatemala participated with the Guatemalan Exporters Association; this agribusiness company focused on cardamom AGROMERC, and the chia seed company APSA export and opened the trade to agriculture, a sector in Central America that has been known to have comparative advantage (WKO, 2012). Since the growth of the European Economic Union, different countries from Eastern Europe have joined the treaty; as a result, they were included in the European Union and Central America Association Agreement (AA) became a route to trade between the regions. The agreement includes the European Union countries and Central American countries, including: Guatemala, El Salvador, Costa Rica, Honduras, Nicaragua and Panamá. The negotiations came to an end in August 2013 with the imminent implementation of the commercial pillar of the Agreement (Approdev, 2013). Since the negotiation, the share of exports from Central America to Eastern Europe, compared to the total exportations from Central America to the World, grew from $17.3 \%$ in 2010 to $19.8 \%$ in 2013. 
Given the growth in commerce between Central America and the European Union, a measurement for studying competitive advantages for trade between commerce could enlighten the reason for future agreements. Balassa (1965) studied the concept of comparative advantages searching for a better measurement concerning the patterns of commerce. In search of an improved solution to the understanding of comparative advantages, the proposal of reveal comparative advantages emerged. The reveling of comparative advantages are obtained through the comparison concerning the flow of goods and services that reflects a real exchange, thereby replicating the relative costs and identifying the differences between countries by other factors not necessary related to markets. (Arias \& Segura, 2004) The comparison of real exchanged is based on the theory of Liesner (1958) that analyzed the export flows of the European Common Market to determine the strong sectors of the British industry. Balassa refined the proposal of Liesner by considering the actual export flows that lead to the revealing of the strong economic sectors and the comparative advantages between countries. The result of this indicator came to be known as the Balassa Index (Hinloopen \& Marrewijk, 2006).

The Balassa Index became important for analyzing the economic unions and free trade agreements under the assumption that the country should export in the most productive industries (Leromain \& Orefice, 2013). Therefore, the study of the actual export comparison concerning Eastern Europe and Central America could lead to conclusions of which industries should be negotiated by each country in a free trade agreement.

Therefore, the Balassa index can identify whether there is a competitive advantage between Central America and Eastern Europe when engaging commerce. The hypotheses are as follow:

H1: Central America has a stronger competitive advantage in comparison with Eastern Europe, consequently motivating a relation in commerce treaty within the nations

H2. Eastern Europe has a stronger competitive advantage in comparison with Central America enhancing their economy through trade.
H3: Neither Central America or Eastern Europe has a strong competitive advantage and the relation in commerce is sterile.

\section{OLS REGRESSION ANALYSIS}

In this study, the data was collected by observing 156 listed firms in the Hanoi and the HoChiMinh Stock Exchange Centers at the end of 2006. It included 780 firms' yearly observations during the period of 2008-2010. By considering the influences of other factors on firm performance, the OLS regression analysis was performed following Model (1). The coefficient estimations of the variables were reported in Table 2. The estimation showed that the percentage of independent directors on a board is negatively correlated to the performance of the firm. Further, the correlations were significant at the 0.01 level, which inversely supported hypothesis 1a. This finding was different from those of previous studies, which indicated a positive or no relationship between independent directors and a firm's performance. Independent directors are "isolated" and more likely to act as reporters to shareholders since they were less involved in the activities of the firm. Their own self-interest in the firm's performance was minimal Fredrickson et al. (1988). However, the effectiveness of these reporters was questioned when they lacked the ability to provide relevant reports to shareholders and had no incentive to improve the performance of their firms. These conditions were observed in developing countries where the qualification of directors was lacking and they might have a negative influence on the firm's performance.

\section{METHODOLOGY FOR COMPARATIVE ADVANTAGES: THE BALASSA INDEX}

The Balassa Index measures the normalized export shares of a group of countries comparing the same industries (Hinloopen \& Marrewijk, 2006). The measurement reflects the degree of importance a certain product has based on the exports from one market to another and compares it to the exports from the market to the world (Durán Lima \& Álvarez, 2008). The formal expression of the index is as follows: 
Where: country $j$

$=$ Exports of product $k$ by country $i$ to

$=$ Total exports from country $i$ to country $j$

$=$ Exports of product $k$ by country $i$ to the world $(w)$ world $(w)$

$=$ Total exports from country $i$ to the

The index has been adapted to compare two economic blocks such as Central America and Eastern Europe. The index can be calculated for different comparisons based on the information of the products and the market analysis. The Index can also be linked to the theory of competitive advantages as Hillman (1980), Bowen (1983), and Vollrath (1991) used it to demonstrate various combinations and transformations. For analyzing the Balassa Index with precision, it is necessary to normalize the result of the index with a maximum of 1 and a minimum of -1 , the process is known as the index of comparative advantages (ICVR). The ICVR is as follows:

The values obtained through the normalization of the index will have a range of -1 and 1 and the results should be interpreted based on the following typology (Durán Lima \& Álvarez, 2008) (See Table 1).

Table 1. Balassa Index clasification

\begin{tabular}{cc}
\hline Scale & \multicolumn{1}{c}{ Advantage/Disadvantage } \\
\hline $0.33<=$ IB $<=1.00$ & Comparative advantage \\
$-0.33<$ IB $<0.33$ & $\begin{array}{c}\text { Tendency towards intra-product } \\
\text { commerce } \\
-1.00<=\text { IB }<=-0.33\end{array}$ Comparative Disadvantage \\
\hline
\end{tabular}

A comparative disadvantage should be interpreted as a negative result that implies that the imports exceed the exports. Comparative advantage demonstrates that the exports from the country are superior to the imports. Intraproduct commerce can also be referred as intraindustrial and reflect that there are industries that can exchange products between the same industry. Verdoorn (1960) and Kojima (1964) analyzed this exchange between industries where the Balassa Index takes into account that the measurement is focused on the sectors.

The usage of the Balassa index has to be guided by product categories and cannot be done by export to import analysis in general. For example, when country (A) is producing and exporting cars, the index is used to analyze if country (B)the country that will receive the exportation-has a strong position in the car industry. Therefore, the Balassa index is the result of a normalized export share (Ballasa, 1965).
To explain the usage of the Balassa Index, the Netherlands Statistics Department (2013) utilizes the following example for the cereal production in 2009:

Export of cereals by the Netherlands: 397 million euro

Total export of the Netherlands: 309,359 million euro

Export of cereals by EU-15 excluding

the Netherlands: 9,916 million euro

Total export by EU-15 excluding the Netherlands: 2,572634 million euro

The Balassa index equals

(397 million / 309,359 million) divided by----------- $=0.3$

(9,916 million / 2,572634 million) 
The outcome is 0.3 so it is less than 1 , which means that the Netherlands has no export specialisation for the export product cereals compared with the EU-15 member states.

\section{Relative advantages of Eastern Europe and Central America}

The analysis of the relative comparative advantage between Eastern Europe and Central America takes into account 22 different sections that represent a category of products that are exchanged by Eastern Europe and Central America. There are 22 different sections that include various products. These products are classified according to industry or final product and are based on the Central American Tariff System and the Uniform Customs Codes for Central America (SIECA, 2013). The sections are described in Table 2. For the analysis, the Eastern Europe the countries included were Russia, Czech Republic, Poland, Hungary, Romania, Croatia, Slovenia, Slovakia, Bulgaria, Ukraine, Serbia, Montenegro, Bosnia and Herzegovina, Albania, Kosovo and Macedonia. Concerning Central America, the countries considered were Guatemala, El Salvador, Honduras, Nicaragua Panamá and Costa Rica based on the circumstances of the AA agreement.

Table 2. Exchange Sections between Europe and Central America

\begin{tabular}{|c|c|c|}
\hline $\begin{array}{l}\text { Section } 1 \text { - } \\
\text { Live animals or } \\
\text { animal product }\end{array}$ & $\begin{array}{l}\text { Section } 2 \text { - } \\
\text { Plant Kingdom } \\
\text { product }\end{array}$ & $\begin{array}{l}\text { Section } 3 \text { - } \\
\text { Fats and oils from } \\
\text { animals or plants }\end{array}$ \\
\hline $\begin{array}{l}\text { Section } 4 \text { - } \\
\text { Beverages, Tabaco, } \\
\text { Vinegar, Alcohol } \\
\text { and other } \\
\text { derivatives }\end{array}$ & $\begin{array}{l}\text { Section } 5 \text { - } \\
\text { Mineral Products }\end{array}$ & $\begin{array}{l}\text { Section } 6 \text { - } \\
\text { Chemical Industry }\end{array}$ \\
\hline $\begin{array}{l}\text { Section } 7 \text { - Plastic } \\
\text { and Rubber }\end{array}$ & $\begin{array}{l}\text { Section } 8 \text { - } \\
\text { Leather Products }\end{array}$ & $\begin{array}{l}\text { Section } 9 \text { - } \\
\text { Wood, Charcoal and } \\
\text { related manufacturing }\end{array}$ \\
\hline $\begin{array}{l}\text { Section } 10 \text { - } \\
\text { Paper or cardboard } \\
\text { products }\end{array}$ & $\begin{array}{l}\text { Section } 11- \\
\text { Textile }\end{array}$ & $\begin{array}{l}\text { Section } 12 \text { - } \\
\text { Hats, umbrellas, } \\
\text { artificial flowers, } \\
\text { footwear }\end{array}$ \\
\hline $\begin{array}{l}\text { Section } 13- \\
\text { Cement and stone } \\
\text { products }\end{array}$ & $\begin{array}{l}\text { Section } 14- \\
\text { Fine and precious } \\
\text { stones and pears }\end{array}$ & $\begin{array}{l}\text { Section } 15-\text { Common } \\
\text { Metals }\end{array}$ \\
\hline $\begin{array}{l}\text { Section } 16 \text { - } \\
\text { Machinery, electric } \\
\text { material, } \\
\text { televisions and } \\
\text { accessories }\end{array}$ & $\begin{array}{l}\text { Section } 17 \text { - } \\
\text { Transport material }\end{array}$ & $\begin{array}{l}\text { Section } 18 \text { - } \\
\text { Photography, } \\
\text { cinematography } \\
\text { products }\end{array}$ \\
\hline $\begin{array}{l}\text { Section } 19- \\
\text { ammunitions and } \\
\text { weapons }\end{array}$ & $\begin{array}{l}\text { Section } 20 \text { - Diverse } \\
\text { products }\end{array}$ & $\begin{array}{l}\text { Section } 21 \text { - Art and } \\
\text { antiques }\end{array}$ \\
\hline $\begin{array}{l}\text { Section } 22 \text { - } \\
\text { Contractors }\end{array}$ & & \\
\hline
\end{tabular}

Note. Adapted by the authors with information from SIECA (2013) 
The index is calculated taking into account these 22 sections and comparing the exports of Central America and Eastern Europe. The calculation of the index, as seen in Table 3, compares the exports of Central America to Eastern Europe and the world to understand the comparative advantages, disadvantages and the tendency towards intra-product commerce.

Table 3: Balasa Index for 2013

\begin{tabular}{ccccccc} 
Section & Description & xkij & xkiw & rca & rca norm & results \\
\hline TOTAL & $1,996.0$ & $10,065.1$ & 1.000 & -
\end{tabular}

\begin{tabular}{|c|c|c|c|c|c|c|}
\hline 01 & $\begin{array}{l}\text { Section } 1 \text { - Live } \\
\text { animals or animal } \\
\text { product }\end{array}$ & 26.9 & 450.6 & 0.302 & -0.537 & $\begin{array}{l}\text { Comparative } \\
\text { Disadvantage }\end{array}$ \\
\hline 02 & $\begin{array}{l}\text { Section } 2 \text { - Plant } \\
\text { Kingdom product }\end{array}$ & 756.2 & $2,716.8$ & 1.404 & 0.168 & $\begin{array}{l}\text { Tendency towards } \\
\text { intra-product } \\
\text { commerce }\end{array}$ \\
\hline 03 & $\begin{array}{l}\text { Section } 3 \text { - Fats and } \\
\text { oils from animals or } \\
\text { plants }\end{array}$ & 25.0 & 284.9 & 0.443 & -0.386 & $\begin{array}{l}\text { Comparative } \\
\text { Disadvantage }\end{array}$ \\
\hline 04 & $\begin{array}{l}\text { Section } 4 \text { - Beverages, } \\
\text { Tabaco, Vinegar, } \\
\text { Alcohol and other } \\
\text { derivatives }\end{array}$ & 409.3 & $1,779.7$ & 1.160 & 0.074 & $\begin{array}{l}\text { Tendency towards } \\
\text { intra-product } \\
\text { commerce }\end{array}$ \\
\hline 05 & $\begin{array}{l}\text { Section } 5 \text { - Mineral } \\
\text { Products }\end{array}$ & 25.9 & 223.1 & 0.585 & -0.262 & $\begin{array}{l}\text { Tendency towards } \\
\text { intra-product } \\
\text { commerce }\end{array}$ \\
\hline 06 & $\begin{array}{l}\text { Section } 6 \text { - Chemical } \\
\text { Industry }\end{array}$ & 30.6 & 611.3 & 0.252 & -0.597 & $\begin{array}{l}\text { Comparative } \\
\text { Disadvantage }\end{array}$ \\
\hline 07 & $\begin{array}{l}\text { Section } 7 \text { - Plastic and } \\
\text { Rubber }\end{array}$ & 15.3 & 462.4 & 0.167 & -0.714 & $\begin{array}{l}\text { Comparative } \\
\text { Disadvantage }\end{array}$ \\
\hline 08 & $\begin{array}{l}\text { Section } 8 \text { - Leather } \\
\text { Products }\end{array}$ & 8.0 & 25.7 & 1.579 & 0.225 & $\begin{array}{l}\text { Tendency towards } \\
\text { intra-product } \\
\text { commerce }\end{array}$ \\
\hline 09 & $\begin{array}{l}\text { Section } 9 \text {-Wood, } \\
\text { Charcoal and related } \\
\text { manufacturing }\end{array}$ & 13.5 & 57.0 & 1.198 & 0.090 & $\begin{array}{l}\text { Tendency towards } \\
\text { intra-product } \\
\text { commerce }\end{array}$ \\
\hline 10 & $\begin{array}{l}\text { Section } 10 \text { - Paper or } \\
\text { cardboard products }\end{array}$ & 5.1 & 247.5 & 0.105 & -0.811 & $\begin{array}{l}\text { Comparative } \\
\text { Disadvantage }\end{array}$ \\
\hline 11 & Section 11 - Textile & 9.4 & 603.1 & 0.078 & -0.855 & $\begin{array}{l}\text { Comparative } \\
\text { Disadvantage }\end{array}$ \\
\hline 12 & $\begin{array}{l}\text { Section } 12 \text { - Hats, } \\
\text { umbrellas, artificial } \\
\text { flowers, footwear }\end{array}$ & 0.1 & 30.7 & 0.022 & -0.957 & $\begin{array}{l}\text { Comparative } \\
\text { Disadvantage }\end{array}$ \\
\hline 13 & $\begin{array}{l}\text { Section } 13 \text { - Cement } \\
\text { and stone products }\end{array}$ & 0.4 & 94.4 & 0.022 & -0.957 & $\begin{array}{l}\text { Comparative } \\
\text { Disadvantage }\end{array}$ \\
\hline
\end{tabular}




\begin{tabular}{|c|c|c|c|c|c|c|}
\hline 14 & $\begin{array}{l}\text { Section } 14 \text { - Fine and } \\
\text { precious stones and } \\
\text { pears }\end{array}$ & 0.5 & 288.3 & 0.009 & -0.982 & $\begin{array}{l}\text { Comparative } \\
\text { Disadvantage }\end{array}$ \\
\hline 15 & $\begin{array}{l}\text { Section } 15 \text { - Common } \\
\text { Metals }\end{array}$ & 43.7 & 411.9 & 0.535 & -0.303 & $\begin{array}{l}\text { Tendency towards } \\
\text { intra-product } \\
\text { commerce }\end{array}$ \\
\hline 16 & $\begin{array}{l}\text { Section } 16 \text { - } \\
\text { Machinery, electric } \\
\text { material, televisions } \\
\text { and accessories }\end{array}$ & 547.7 & $1,117.9$ & 2.471 & 0.424 & $\begin{array}{l}\text { Comparative } \\
\text { Advantage }\end{array}$ \\
\hline 17 & $\begin{array}{l}\text { Section } 17 \text { - Transport } \\
\text { material }\end{array}$ & 0.5 & 43.3 & 0.056 & -0.893 & $\begin{array}{l}\text { Comparative } \\
\text { Disadvantage }\end{array}$ \\
\hline 18 & $\begin{array}{l}\text { Section } 18 \text { - } \\
\text { Photography, } \\
\text { cinematography } \\
\text { products }\end{array}$ & 77.3 & 492.8 & 0.791 & -0.117 & $\begin{array}{l}\text { Tendency towards } \\
\text { intra-product } \\
\text { commerce }\end{array}$ \\
\hline 19 & $\begin{array}{l}\text { Section } 19- \\
\text { ammunitions and } \\
\text { weapons }\end{array}$ & 0.0 & 0.0 & 0.090 & -0.835 & $\begin{array}{l}\text { Comparative } \\
\text { Disadvantage }\end{array}$ \\
\hline 20 & $\begin{array}{l}\text { Section } 20 \text { - Diverse } \\
\text { products }\end{array}$ & 0.3 & 123.3 & 0.012 & -0.977 & $\begin{array}{l}\text { Comparative } \\
\text { Disadvantage }\end{array}$ \\
\hline 21 & $\begin{array}{l}\text { Section } 21 \text { - Art and } \\
\text { antiques }\end{array}$ & 0.0 & 0.1 & 0.149 & -0.741 & $\begin{array}{l}\text { Comparative } \\
\text { Disadvantage }\end{array}$ \\
\hline 22 & $\begin{array}{l}\text { Section } 22- \\
\text { Contractors }\end{array}$ & 0.0 & 0.4 & 0.335 & -0.498 & $\begin{array}{l}\text { Comparative } \\
\text { Disadvantage }\end{array}$ \\
\hline
\end{tabular}

When analyzing the different years for the comparative advantage by products, the competitive disadvantage is extremely high for Central America; therefore the relation of commerce between Eastern Europe and Central
America behooves Eastern Europe. Table 4 demonstrates the percentage of comparative advantage that Central America has over Eastern Europe.

Table 4. Revealed Comparative Advantages- Central America to Eastern Europe

\begin{tabular}{lrrrr}
\hline \multicolumn{5}{c}{ Revealed Comparative Advantages } \\
\hline \multicolumn{5}{c}{ Central America to Eastern Europe } \\
IB result & 2010 & 2011 & 2012 & 2013 \\
Comparative Advantage & $4.5 \%$ & $4.5 \%$ & $4.5 \%$ & $4.5 \%$ \\
Comparative Disadvantage & $63.3 \%$ & $54.5 \%$ & $59.1 \%$ & $63.6 \%$ \\
\hline Tendency towards intra-product commerce & $31.8 \%$ & $40.9 \%$ & $36.4 \%$ & $31.8 \%$ \\
\hline
\end{tabular}

Note. Adapted by the author with information from SIECA (2013)

In this case, the comparative advantage of Central America is minimum compared to Eastern Europe. Only one section has a comparative advantage and is the section 16 that refers to machinery, electric material, televisions and accessories. This comparative advantage is constant for the four years of analysis indicating that no other section has become a comparative 
advantage through time.

The comparative disadvantages have shown certain fluctuation in the four years. For year 2010, Central America showed disadvantage in sections $1,3,6,7,10,11,12,13,14,17,19,20,21$, 22 . The difference for year 2011 was that sections 21 and 22 became a tendency towards intraproduct commerce. Year 2012 presented a change in section 3 that went from comparative disadvantage to tendency towards intra-product commerce and for year 2013 section 14 became a comparative disadvantage that lead to a result of $63.6 \%$ of the sections in this category.

\section{DISCUSSION}

Analyzing the competitive advantages of two different geographic regions has been explored in economic theory since Ricardo proposed his model more than a century ago. However, most studies analyzing the competitive advantage of regions have been a 'reactive' process. In other words, studies dealing with competitive advantage have researched the results of trade after this has been carried out. Thus, the validity of analytical tools used to predict competitive advantages between two regions has not been fully covered in the relevant literature. For that reason, it is important to study the competitive advantage of a proposed FTA before it happens, which is the purpose of this paper. In order to fill this gap in the literature, this study offers a study regarding the possible outcomes of an FTA between two very different geographical regions.

The Balassa Index offers a context for a commerce relation between Central America and Eastern Europe. In the case of Central America, engaging in a trade agreement with Eastern Europe would not be a helpful strategy since there almost no competitive sector they can take advantage. As explained in the index analysis, only section 16 , machinery and electric material, could offer a competitive advantage for Central America. As a result, the discussion of a free trade agreement with the Eastern Europe can only benefit Central America if it is settled for section 16 and if other sections are included in a free trade agreement, then Central America should engage in a strategy for intra-product commerce based on specific industries. This second aspectthe aspect of intra-product commerce-may be of interest to Eastern Europe since an average of approximately $52 \%$ of the sections portfolio leans toward intra-product commerce.

Even so, a free trade agreement for the 22 sections will benefit Eastern Europe greatly since Central America has competitive disadvantages and a low tendency to intra-product commerce. In terms of benefits of free trade and exchange, an agreement with Central America and Eastern Europe is of no urgency to the other since the comparative advantage is not significant. The Balassa Index indicates that, for Central America, there is no benefit in the trade unless they only focus on the section 16 because they have a low tendency for intra-product commerce and the benefit is not clear in terms of strategy. Therefore continuing with the AA program with the European Union seems as a better aspect to implement competitive advantages.

\section{CONCLUSION}

This study demonstrates the validity of the Balassa Index and the importance for analyzing commerce between economic blocks. This paper analyzed the exports of Central America to Eastern Europe and the World with the purpose of determining the possibility of a free trade agreement between the two economic groups. The index demonstrated that, for Central America, the only benefit is if they negotiate only the section 22 specific contracts between countries that are not included in the other sections. Taking into account that free trade agreements are not negotiated based on one section, the possibility of a free trade agreement that could benefit Central America is microscopic. As a result, there is no urgency for a free trade agreement between this to economic groups. Additionally, it may be expanded for a long-term strategy.

Concerning the long-run strategy: the best way to implement a free trade agreement is to expand the products of the two sections that have a competitive advantage and to diversify the exportations from Central America to Eastern Europe and vice versa. Establishing an agreement concerning trade between the sections in which Central America has competitive advantage will behoove the development of the region because of the sections' growth. If Central America negotiates in products that do not present competitive advantages the results will affect the economy because of the dependence on Eastern Europe and because of their competitive 
advantages. The engagement in diversification will lead to a clearer indicator and a better analysis for a future economic strategy between Central America and Eastern Europe.

It is important to consider in further studies the analysis between Central America and other economic blocks to infer if treaties have been signed on competitive advantages on what modifications could be made when negotiating products. The analysis of the Balassa Model could lead to better negotiations and benefits when negotiating between countries.

\section{REFERENCES}

Anchorena, S. (2009). Comercio Internacional: Ventaajs Comparativas, Desventajas Distributivas. Entrelíneas de la Política Económica, 3(23), 25-37.

Approdev. (2013). EU amd Central American Union Association Agreement. Retrieved November 15, 2013, from http://www.aprodev.eu/index. php?option=com_content $\&$ view=article $\&$ id $=92 \& I t$ emid $=43 \&$ lang $=$ en

Arias-Segura, J., \& Segura-Ruiz, O. (2004). Índice de ventaja comparativa revelada: un indicador del desempeño y de la competitividad productivocomercial de un país.

Coronado, Costa Rica: Instituto Interamericano de Cooperacion para la Agricultura.

Balassa, B. (1965). Trade liberalization and revealed comparative advantage. The Manchester Business School of Economic and Societal Studies, 99-123.

Behrman, J. (1974). Decision criteria for foreign direct investment in Latin America. New York: Concil of the Americas.

Benedictis, L., \& Tajoli, L. (2007). Economic Integration and Similarity in Trade Structures. Empirica , 34(2), 117-137.

Biglaiser, G., \& De Rouen, K. (2006). Economic reforms and inflows of foreign direct investment in Latin America. Latin American Research Review, 41, 5175.

Bowen, H. (1983). On the theoretical interpretation of indices of trade intensity and revealed comparative advantages. Weltwirtschaftliches Archiv, 119, 464-742.

Cai, J., Leung, P., \& Hishamunda, N. (2009). Assessment of comparative Framework and application on selected species. Rome: FAO.

Dinan, D. (2005). Ever Closer Union: An Intruduction to European Integration (3rd ed.). Boulder: Lynne Rienner Publishers.

Durán Lima, J. E., \& Álvarez, M. (2008). Indicadores de comercio exterior y política comercial: mediciones de posición y dinamismo comercial. Retrieved from www.eclac.cl: http://www.eclac.cl/ comercio/publicaciones/xml/7/34897/Mediciones _Posicion_Dinamismo_Comercial_LCW217.pdf

Duran-Lima, J., \& Alvarez, M. (2003). Manual de Comercio Exterior y Politica Comercial: Nociones Basicas, Clasificaciones e Indicadores de Posicion y Dinamismo. Santiago: CEPAL.

European Commission. (2013). Economic and Monetary Union. Retrieved from http://ec.europa.eu/economy_finance/euro/emu/

Grosse, R. (1989). Multinational in Latin America. London: Routledge.

Hillman, A. (1980). Observations on the relation between "Revealed comparative advantages" and "comparative advantages" as indicated in pretrade relative prices. Weltwirtschaftliches Archiv , $116,315-321$.

Hinloopen, J., \& Marrewijk, C. (2008). Empirical relevance of teh Hillman condition for revealed comparative advantage: 10 stylized facts. Applied Economics, 40, 2313-2328.

Hinloopen, J., \& Marrewijk, C. (2001). On the empirical distribution of the Balassa Index. Review of World Economics, 137, 1-35.

Hobday, M. (1995). Innovation in East Asia: The Challenge to Japan. Tokio: Edward Elgar.

Hunt, S., \& Morgan, R. (1995). The Comparative Advantage Theory of Competition. Journal of Marketing, 59, 1-15.

Kojima, K. (1985). The "Flying Geese" Model of Asian Economic Development: Origin, Theoretical Extensions, and Regional Policy Implications. Hitotsubashi Journal of Economics, 11(4), 99-116.

Kojima, K. (2000). The "Flying Geese" Model of Asian Economic Development: Origin, Theoretical Extentions, and Regional Policy Implications. Journal of Asian Economics, 11 (4), 375-401.

Kojima, K. (1964). The Pattern of International Trade Among Advanced Countries. Hitotsubashi Journal of Economics, 5(1), 16-36.

Kose, A., \& Rebucci, A. (2005). How might CAFTA change macroeconomic fluctuations in Central America? Lessos from NAFTA. Journal of Asian Economics, 16(1), 77-104.

Lee, E., Rhee, Y., \& Lee, S. (2013). Beyond Ricardian Model: An Optimal Commodity Distribution Based on Absolute Advantage for Multi-Country MultiCommodity. International Journal of Business and Management, 8(14), 110-114.

Leromain, E., \& Orefice, G. (2013). New Revealed Comparative Advantage Index: dataset and empirical distribution. Paris: CEPII.

Liesner, H. (1958). The European Common Market and British Industry. Economic Journal, 68, 302-316. 
Polanco, R. (2012). El Modelo Ricardiano de Ventaja Comparativa y el Comercio Contemporaneo: El Caso del Sector de "Equipos de Transporte" en la Industria Manufacturera. Ciencia y Sociedad, 34(4), 529-555.

Ricardo, D. (1951). The Theory of Comparative Advantage. In P. Sraffa, \& M. Dobbs, The Works and Correspondence of David Ricardo (Vol. 1). Cambridge: Cambridge University Press.

Rivera-Batiz, F. (2000). Foreign Direct Investment in Latin America: Current Trends and Future Prospects. New York: Columbia University Press.

Rodrik, D. (1996). Understanding Economic Policy Reform. Journal of Economic Literature, 34, 9-41.

Samuelson, P. (1969). The Way of an Economist. International Economic Relations: Proceedings of the Congress of Economic Association (pp. 1-11). London: MacMillan .

SICE. (2005). Sistema de Informacion Sobre Comercio Exterior. Retrieved from SICE: www.sice.oas.org/ sica/bkgrd_s.asp

Soto-Acosta, W. (1986). El Mercado Comun Centroamericano y la Cuestion de la Burguesia Gerencial. Ciencias Sociales, 32, 85-97.

Summa, T. (2008). The European Union's 5th Enlargement: Lessons Learned. Harvard University. Cambridge: Harvard University Press.

Sutherland, K. (2008). An Inquiry into the Nature and Causes of the Wealth of Nations: A Selected Edition. London: Clays Ltd.

Trevino, L., Mixon, \& F. (2004). Strategic factors affecting foreign direct investment decisions by multi-national enterprises in Latin America. Journal of World Business, 39, 233-243.

Verdoon, R. (1960). The Intra-Block Trade of Benelux. (E. Robinson, Ed.) London: MacMillan.

Vollrath, 1. (1991). A theoretical evaluation of alternative trade intensity measures of revealed comparative advantage. Weltwirtschaftliches Archiv, 127, 265-280.

WKO. (2012). Latin America Meets Central and Eastern Europe in Vienna. Retrieved from WKO: http://www.b2match.eu/lameetscee

\section{ABOUT THE AUTHORS}

Corresponding author: Mauricio Garita, email: mauriciogaritag@gmail.com

Dr. Mauricio Garita is a professor in the Faculties of Economics and Political Science at the Universidad Rafael Landivar, Guatemala. His main research focuses on economic history, game theory, development and sociology. He obtained his Doctorate from the Universidad Pontificia de Salamanca in Political Science and Sociology. He has published books, chapters and papers in the subjects of game theory, economic history, war and underdevelopment, sociology and international economics.

Dr. Jose Godinez is a Visiting Assistant Professor of Strategy at Merrimack College, North Andover, MA. His main research areas are the issues faced by Latin American multinationals when internationalizing. He has fulfilled the requirements to receive the degree of doctor of philosophy in management from the University of Edinburgh Business School. He has also presented his work at prestigious international business conferences and is member of the Academy of International Business and the Academy of Management. 
Appendix

\begin{tabular}{|c|c|c|c|c|}
\hline \multicolumn{5}{|c|}{ Central America to Eastern Europe } \\
\hline \multicolumn{5}{|c|}{ Indicator Average (2010-2013) } \\
\hline $\begin{array}{l}\text { Secti } \\
\text { on }\end{array}$ & $\begin{array}{l}\text { rca norm } \\
(2010)\end{array}$ & $\begin{array}{l}\text { rca norm } \\
(2011)\end{array}$ & $\begin{array}{l}\text { rca norm } \\
(2012)\end{array}$ & $\begin{array}{l}\text { rca norm } \\
(2013)\end{array}$ \\
\hline 1 & -0.395 & -0.399 & -0.348 & -0.537 \\
\hline 2 & 0.234 & 0.231 & 0.211 & 0.168 \\
\hline 3 & -0.661 & -0.404 & -0.054 & -0.386 \\
\hline 4 & -0.192 & -0.142 & -0.269 & 0.074 \\
\hline 5 & -0.256 & -0.330 & -0.309 & -0.262 \\
\hline 6 & -0.912 & -0.792 & -0.662 & -0.597 \\
\hline 7 & -0.779 & -0.764 & -0.771 & -0.714 \\
\hline 8 & 0.152 & 0.010 & -0.087 & 0.225 \\
\hline 9 & -0.060 & 0.170 & 0.157 & 0.090 \\
\hline 10 & -0.929 & -0.895 & -0.852 & -0.811 \\
\hline 11 & -0.892 & -0.856 & -0.821 & -0.855 \\
\hline 12 & -0.962 & -0.928 & -0.936 & -0.957 \\
\hline 13 & -0.970 & -0.975 & -0.978 & -0.957 \\
\hline 14 & -0.951 & -0.950 & -0.974 & -0.982 \\
\hline 15 & -0.097 & -0.098 & -0.195 & -0.303 \\
\hline 16 & 0.491 & 0.461 & 0.470 & 0.424 \\
\hline 17 & -0.851 & -0.848 & -0.790 & -0.893 \\
\hline 18 & -0.157 & -0.071 & -0.025 & -0.117 \\
\hline 19 & -0.959 & -0.598 & -0.986 & -0.835 \\
\hline 20 & -0.694 & -0.766 & -0.965 & -0.977 \\
\hline 21 & -0.717 & -0.275 & -0.466 & -0.741 \\
\hline 22 & -0.438 & -0.323 & -0.439 & -0.498 \\
\hline
\end{tabular}

Note. Adapted by the authors with information from Sieca (2013) 